\title{
THE MOTIVATIONS OF CONNIE'S ADULTERY WITH MELLORS IN THE NOVEL LADY CHATTERLEY'S LOVER
}

\author{
Mukhlasul Fasikh \\ STIBA-IEC Jakarta \\ mukhlasul@stibaiecjakarta.ac.id
}

\begin{abstract}
This objective of this research is to add to the students' knowledge of the Connie's motivation in committing adultery. In addition, the objectives are to find out the character of Connie, to give evidence and find out the motivation of Connie's adultery with Mellors then to know the reaction of Clifford to students, teachers and people who want to analyze the Connie's motivation in committing adultery. This research is a library research. The research was done through reading the novel and other sources related to the motivation of Connie's adultery. The data was taken from books, dictionary, and internet. The researcher uses qualitative method to analyze the motivation of Connie in committing adultery. The novel tells about Connie as the female protagonist of the novel. At 23, she marries Clifford Chatterley. After a month's honeymoon, Clifford is sent to war, and returns paralyzed from the waist down and become impotent. After that, he becomes a successful writer. Into the void of Connie's life comes Oliver Mellors, the gamekeeper on Clifford's estate. Connie feels curiously drawn to him. After several meetings him, they meet by chance at a hut in the forest. And they have sex more than twice. This time, Connie begins to adore Mellors. She is proud to believe that she is bearing Mellors' child. Adultery means he or she physically engages in sexual acts with someone who is not his or her spouse. They commit adultery due to several motivations such as the weaknesses of their partner, chances to meet their paramour that grow them in love. Understanding of the people's motivation in committing adultery is very important before judging them unpleasantly.
\end{abstract}

Key words: motivations, committing adultery, characterization

\section{A. INTRODUCTION}

\section{Background}

Why is literature read by many people? The basic reason for reading literature is for pleasure. Many readers read literature mostly because they 
enjoy it. A literature entertains people by showing the beauty and giving the value to the life or giving the freedom to imaginative world (Melani Budianta: 2003). Then according to Jones (1968) literature is also simply another way we can experience the world around us through our imagination.

Literature can be defined as a work that tells about the characters which sometimes can be found in someone's real life. It also gives not only entertainment and information, but it also shows the readers how to live in this world properly.

A novel has some elements of structure to help the readers analyze it. They are plot, characterization, situation and theme, conflicts and point of view. Theme is one of the most basic elements of a novel. And the writer would like to analyze it in this novel in depth. The title of this novel is Lady Chatterley's Lover written by Lawrence. The writer decided to work on this novel because it is one of the controversial novels in modernism period as a pornography work.

These days, adultery is hardly surprising. The theme of story about adultery, even fiction or non fiction, is easily found in the books and movies. This is the fact of adultery has been part of the human existence for as long as there has been marriage. People who commit adultery have many different motivations. Even adultery brings the great problems, there are many people commit adultery. The writer is interested in digging much information related to the motivations of Connie's adultery with Mellors which can be seen during his activity, self-concept and thought as described explicitly in the novel.

Lady Chatterley's Lover begins by introducing Connie Reid, the female protagonist of the novel. She was raised as a cultured bohemian of the uppermiddle class in 1917. At 23, she marries Clifford Chatterley. After a month's honeymoon, he is sent to war, and returns paralyzed from the waist down, impotent. After the war, Clifford becomes a successful writer. Connie feels isolated; she commits adultery with Michaelis in his visit to Clifford. A nurse, Mrs. Bolton, is hired to take care of Clifford

Into the void of Connie's life comes Oliver Mellors, the gamekeeper on Clifford's estate. Connie feels curiously drawn to him. After several chance meetings, Mellors tries to avoid and make distance. They meet by a chance at 
a hut in the forest. They have sex. It happens on several occasions, but Connie still feels a distance between them. One day, Connie and Mellors meet by coincidence in the woods, and they have sex on the forest floor. This time, Connie gets something nice and different from Mellors. She begins to adore Mellors. She is proud to believe that she is pregnant with Mellors' child. The motivations of Connie in committing adultery to Mellors will be discussed more in this thesis. So the writer will discuss deeply about Connie's motivation in committing adultery.

\section{The Objectives}

Based on the problem above, the objectives of this study are:

1) To find out the Connie's characterization

2) To identify how often Connie commits adultery.

3) To get the reasons that Connie commits adultery with Mellors.

4) To elaborate the reaction of Connie's husband about her adultery.

\section{Theoretical Framework}

\subsection{Character}

\subsubsection{Definition of Character}

A character is the focus of much existing genre theory. This usually involves much fine-drawn moral analysis, since character is the personal form of values (Fowler: 1982). And then, according to Obstfeld (2002) it can be defined as any person, persona, identity, or entity that exists in work of art. Along with plot setting theme and style, character is considered one of the fundamental components of fiction.

Richard (1995:127) stated that Character is someone in literary work that has some sort of identity, an identity which is made up by appearance, conversation, action, and named possibly thought going on in the head. It is concluded that the character is an imaginary person represented in a work of fiction. Such as in prose, play or film or story, and especially Novel which has a big number of character. 


\subsubsection{Kinds of Characters}

\section{a. Flat character}

According to Ginny (2009), A flat character is a minor character in a work of fiction that does not undergo substantial change or growth in the course of a story. Some characters are flat, stereotypical: the handsome prince, the heroic soldier, the lovely princess, the evil counselor. A flat character is constructed around single idea or quality (Tormina:2005).

\section{b. Round character}

Strong characters are rounded; they exhibit the full range of human emotions and reactions to people and events. They have histories and more than one possible future. They have hopes and fears.

\section{c. Dynamic character}

In a story, a dynamic character is someone who undergoes an important, internal change because of the action in the plot. Ebenezer Scrooge, from Charles Dickens's A Christmas Carol, is a classic example. When we first meet him, he is mean, bitter, and avaricious. Through his experiences with the three ghosts, he becomes generous, kind, and beloved (Cliffs Notes: 2000).

\section{d. Static character}

A static character is one whose personality doesn't change throughout the events in the story's plot. Dickens, again, is the source of an example in Joe Gargery, from Great Expectations. Joe remains faithful, honorable, and loyal despite being robbed by a convict and treated poorly by his wife and nephew.

\section{e. Protagonist}

Protagonist is the main character in a story, novel, drama or other literary work. Then it is added that protagonist is the mayor or central character of the plot (James H Pickering and Jeffrey D. Hoeper, 1995:24).

\section{f. Antagonist}


The antagonist in a work of fiction is the character who opposes the hero or protagonist. Then protagonist is the character against whom the protagonist struggles or commends. The action of story arises from conflict between the antagonist and the protagonist.

\subsection{Adultery}

\subsubsection{Definition of adultery}

What is adultery? There are two definitions to it. It is divided based on the act and the thought. They are:

a. The act; a married person commits adultery if he or she physically engages in sexual acts with someone who is not his or her spouse.

b. The thought; A married person commits adultery if he or she has a lustful desire for someone other than his or her spouse.

Adultery is the affair, which has sexual involvement with someone else that is kept secret from the spouse (Jack Dominian, 1995:163). It can be concluded that adultery is a crime and sexual relations outside of marriage, and adultery may result in pregnancy, and the laws of the country that cover termination of a pregnancy and of child support come into play.

\subsubsection{Cause of adultery}

A person commits adultery when there's something that triggers them to act, and defy their own vows that were made during their wedding day. A lot of possible reasons can cause adultery. A simple example would be physical attractions.

Dr. Weil (2002) has a three part theory to help explain the occurrence of adultery:

a. Adultery is most often the result of an inherited emotional behavior pattern, rather than a desire to be unfaithful.

b. Many men commit adultery because of psychological distress that comes from confrontation or conflict in their relationship. 
c. Some people who have experienced severe stress, loss or separation from one or both of their parents at an early age often suffer an impact on their hormones that affects adult relationships.

A woman commits infidelity when she thinks that they have found the perfect man to become a part her life. A man that she can't have because she's tied to someone else, which in most cases, the husband or partner has become less attractive and appealing for some reason that even she is sometimes unsure of him.

When a woman generates affairs with a man, she may have several reasons that made her do such a thing. Comparing the husband to the new man in her life one that can provide what she feels she is now missing. Things such as a lust for sex, money, power, are pretty selfexplanatory. These reasons are pretty much the same as why men have affairs, financial problems, trust and faithfulness issues, love and such, women goes through the same type of things.

\subsection{Motivation}

\subsubsection{Definition of motivation}

When many people want to do some activites whether pleasure activites or unplesure activities, they have some chances or motivations to do them. And the goal motivates the doers do what they want to do spiritly and full of power. Motivate is making somebody want to do some thing, especially something that involves hard work and effort (A.S. Hornby, 2005:995) . Motivation gets us going; it gives us energy, directs us to toward our goals and sustains us through the task we undertake (Wilma Vialle,Pauline Lysaght, Irina Verenikina. 2005:156) .

Motivation is a reason or reasons behind a character's action (Michael J Cummings: 2009). Besides, motivation is to inspire people to work, individually or in groups in the ways such as to produce best results. It is the willingness to exert high levels of effort towards organizational 
goals, conditioned by the efforts and ability to satisfy some individual need. Motivation is getting somebody to do something because they want to do it (Shah.Ken and Prof. Param J. Shah: 2010).

\subsubsection{Type of motivation}

There are two main broad categories of motivation; intrinsic motivation and extrinsic motivation.

\section{a. Intrinsic motivation}

Intrinsic motivation comes from within (Donna Ambler Peters, Tad McKeon. 1998). It comes from the personal enjoyment and educational achievement that we derive from doing that particular thing. For example for people who love music, their motivation to practice the instrument, attend classes, etc. is intrinsic motivation.

On the flip side, the weakness of intrinsic motivation is that it is more difficult to obtain. It is not always easy to have intrinsic motivation for the thing that you wish to have motivation for. Often times, having intrinsic motivation depends heavily on an individual's personal interests and preference

\section{b. Extrinsic motivation}

Extrinsic motivation is doing something for someone else. Then, extrinsic motivation is motivation that comes from things or factors that are outside the individual.

Extrinsic motivation on the other hand, is easier to engineer. We can use a combination of rewards, pleasure, pain and fear to create motivation for ourselves and others. In addition to that, we can further enhance the effect of extrinsic motivation by effectively using either moving toward or moving away motivation. Extrinsic motivation can be further categorized into moving towards motivation and moving away motivation. 


\section{Methodology}

The writer uses qualitative research to analyze Lady Chatterley's Lover novel. The type of research has been chosen since it is suitable for analyzing novel. Descriptive research design is a scientific method which involves observing and describing the behavior of a subject without influencing it in any way (L.R. Gay and Peter Airasian. 2000).

\section{B. FINDINGS AND DISCUSSIONS}

\section{Connie's adultery with Mellor}

\subsection{The Characterization of Connie}

A character who is categorized as protagonist in Lady Chatterley's Lover is Connie. She has a husband named Clifford Chatterley. She loves her very much but since she meets Mellors, a gamekeeper of Clifford in the woods, her love to Clifford changes gradually until she has hatred to Clifford. As soon as she doesn't like Clifford, she becomes totally in love with Mellors.

From the first Chapter, the affection and attention of Connie to Clifford is shown very romantically. It looks like a true love and everlasting married. But, in the fifth chapter, she meets Mellors in the woods after talking about having child with her beloved husband. Since she meets Mellors in the woods, Connie feels that there is a strong inner beauty in Mellors. She then often likes to spend time and breathe the fresh air to the woods. She also often meets Mellors until they commit adultery in the hut and love each other.

Classification of Connie's character is a round character. It is described in detail during the love making with Clifford and Mellors in her life. She also has hopes and fears in her love to Mellors.

Another classification is that Connie belongs to dynamic character because she has significant changes in her behavior and character. The changes occur when she has met and committed adultery with Mellors. At the first meeting with Mellors, it does not bring the difference behavior of Connie. She still loves Clifford 
even though he is paralyzed and rendered impotent. But, the second trigger of her characterization change is that she commits adultery in hut with Mellors.

It is also important to note that Connie is an extremely careful. First, she loves and takes care of her husband with full of affection and attention, even after he is shipped home paralyzed and impotent. She treats him without any demand. Connie feels pity. Connie tries to understand the condition of Clifford. In the novel, it is written that:

Then, he was pronounced a cure, and could return to life again, with the lower half o his body, from the hips down, paralyzed for ever. (P. 1/I)

Then, Connie is a dramatic character. The writer gets the Connie's dramatic characterization from what Connie says about her self in the letter. It is written that she is also impatient and selfish person.

Dear Clifford, I am afraid what you foresaw has happened. I am really in love with another man, and do hope you will divorce me........ I am not really the right for you. I am too impatient and selfish, I suppose. ......... so do forgive me and get rid of me. (p. 306/XIX)

The last characterization is that Connie is a narcissistic person because she often watches her body naked in front of the mirrors.

When Connie went up to her bedroom, she did what she had not done for long time: took of all her clothes, and look at herself naked in the huge mirror. She didn't know what she looking for, or at, very definitely, yet she moved the lamp till it shone full of her. (P. 71/VII)

It indicates that she has done it when she was young. She does it because she feels lonely. 


\subsection{The Connie's Adultery with Mellors}

There are several times in Connie's meeting with Mellors before they commit adultery in woods. After those meetings, they commit adultery more than three times and their loves grow gradually. Here are the sequences of the Connie's meeting with Mellors: The first meeting happens in the fifth chapter. After Connie and Clifford talk about talk about their life together. Connie is introduced by Clifford in the hut with Mellors.

"Connie, this is the new gamekeeper, Mellors. You haven't spoken to her lady ship yet, Mellors?"

"No, Sir" came the ready neutral words. (p. 46/V)

The second meeting is written in chapter six. The meeting between Connie and Mellors is in the hut coincidently. Connie hears a child crying then she gets closer to the sounds. She meets Mellors getting angry to his child. She asks to Mellors about the reason of this matter.

"What is the matter? Why is she crying?" demanded

Constance, peremptory but a little breathless. (p. 59/VI)

The third meeting still takes place in chapter six. In this meeting, Connie meets Mellors in his Cottage. Connie gets message from Clifford to send a message to Mellors. Near the cottage, Connie looks Mellors soaping his body.

The forth meeting is written in Chapter eight. When she goes to woods, she hears someone hammering something. Then she walks on listening and finds Mellors that is hammering the cage for the young chicks.

The fifth meeting is in chapter eight. In this chapter, Connie gets together again in the hut but it is different from the previous meeting. She meets Mellors when Connie takes shelter in the hut from the rain.

The last meeting before the adultery is written in chapter ten. This meeting is gone on the hut again. In that time, Mellors wants to give key to Connie because she looks unhappy in the previous meeting. 
Afterwards, she gets the key from Mellors, she almost everyday goes to the hut to get her cheerfulness.

In chapter ten, Connie also starts committing adultery with Mellors in the hut. The first adultery begins after the sixth meeting. This is the preliminary point of Connie in getting great affection since she gets married with Clifford. It starts when Connie feels lonely in her life. It makes Connie crying in front of Mellors.

Mellors feels pity. He tries to make her become calm and gives more attentions to her.

Then, Mellors invites her to the hut because he knows that Connie's heart is really broken.

Connie goes to the hut together with Mellors. In the hut, they commit adultery for the first time.

The second adultery also takes place in chapter ten. In this adultery, they do it in the hut in the evening in the drizzle time. She enters the hut with the key that she gets from Mellolrs. Connie offers herself and she really wants to have sex again.

The fourth adultery between Connie and Mellors is in chapter fourteen. This chapter starts when Connie walks to the woods gate to meet Mellors. She waited for Mellors there. She gets outs from her bedroom silently and unseen. This adultery takes place in the Mellors cottage. They make promise to live together because of love.

It is clearly seen that Connie and Mellors want to live together. Both Connie and Mellors have found their love growing gradually.

The next adultery, that is the fifth one, is in chapter fifteen. This adultery is quite strange because they commit adultery under the heavy rain on the ground floor of woods. It makes all their hair and naked body become wet.

Then, Mellors follows Connie's step to have rain together out side. They run after each other and commit adultery outside the hut.

The sixth adultery of Connie and Mellors is in chapter sixteen. It happens at Mellors' cottage in the evening. Connie drops by Mellors cottage before she continues her trip to Venice, Italia by Hilda's car. She stays just only one night. In 
this time, Mellors knows Connie's sister or the first time. In the next morning Hilda will pick her up to go to Venice, Italy.

The last adultery in this novel between Connie and Mellors is in chapter eighteen. London is a city where they have adultery. Mellors sends a letter to Connie's room in the hotel Hartland. Mellors waits for Connie outside the golden Cock in Adam street at seven.

\subsection{The motivations of Connie's adultery with Mellors}

The paralyzed of Clifford from the waist down is one of the triggers in Connie's adultery with Mellors that is written in the first chapter. The extrinsic motivation here creates the intrinsic motivation in Connie's life. Connie feels the physical injustice toward her that makes lonely and there is no hope again if she still continues her life with Clifford. Clifford will not be able to touch Connie with her affection like the other husbands that treat their wives appropriately.

The next motivation of Connie and Mellors is that there are a lot of chances to meet each others. It is classified as extrinsic motivation. In Lady Chatterley's Lover, the writer finds more than five meetings before they commit adultery.

Love is gradually grown between them. It creates strong feeling in Connie and Mellors to commit adultery. This motivation belongs to extrinsic motivation that is categorized into moving toward motivation because Connie tries to achieve their cheerfulness with mellors. Connie feels comfort and gets happiness more when she is beside Mellors.

Then, Mellors invites her to the hut because he knows that Connie's heart is really broken. Those words really touch the Connie's heart.

Connie goes to hut together with Mellors. In the hut, they commit adultery for the first time. Mellors shows his care to Connie. He wants to make Connie feel comfortable beside him.

The strange motivation is that the writer gets is the Clifford's permission to Connie in having sex with other man getting the child. Getting allowance from her 
husband to commit adultery is kind of extrinsic motivation.. And Clifford ever allows her to make love with other man in same degrees of aristocrat not from low level social status.

Clifford still believes her natural instinct. Then Connie meets Mellors in the hut in chapter five. After several meeting, Connie falls in love to Mellors, a man who is not from aristocrat, working as gamekeeper in Clifford's estate. Connie is afraid that Clifford will be angry with her as he has sex with a man who is from low social status.

Clifford wants his child better than him physically. He wants his child carry on the business later as inheritor.

\subsection{The Reaction of Clifford}

The first Clifford's reaction after he hears about the adultery of Connie with Mellors is that he feels shock to hear that information. He gets angry with both Connie and Mellors. Clifford hears that scandals of his wife from the citizen.

The next reaction from Clifford is that he fires Mellors because he hears that the scandal of Mellors is with Connie. Mellors sends letters to Connie and informs that he has been fired by Clifford as a gamekeeper in his estate.

Connie keeps sending letters to Clifford in the beginning chapter nineteen. It tells that Connie asks to be divorced by Clifford because she has another man that she loves to.

This letter makes Clifford sad and he absolutely refuses about what Connie says. Then Clifford asks Connie to go home from London to admit her adultery with Mellors face to face.

He also asks Connie to go to Wragby by sending letter to London. Then Connie answers the letter and she still doesn't want to go to Wragby But Clifford forces Connie to come.

Finally Connie comes to Wragby and she is accompanied by Hilda. At the beginning Connie tries to convince that her adultery just only with Duncan Forbes not with Mellors. Clifford still doesn't believe to Connie about her love with Duncan 
Forbes. After several minutes, Connie tells the truth to Cilliford that Mellors is her love.

\section{CONCLUSION}

Committing adultery is one of the problems that create divorced in some people's married life. They commit adultery because they have their own motivations. The same case of adultery is found in Lady Chatterley's Lover. Based on the discussion, the motivations of Connie's adultery with Mellors can be found even with both intrinsic and extrinsic motivations. This adultery generates a divorce because their love gradually becomes visible in their heart. First, the writer finds the motivation of adultery in the first chapter, such as the paralyzed of Clifford from the waist down and the Clifford's impotent. Then it is defined from the allowance of Clifford for Connie to have a child from another man.

Connie's adultery with Mellors has not only one motivation but also has more than two motivations. The other motivations in Connie's adultery between Mellors are such as there are a lot of chances to meet each others, Love gradually grows between them, and Clifford gives permission to Connie in having sex with other man for getting the child. From those motivations above, they trigger Connie to commit adultery. This adultery emerges the reaction of Clifford as a legal husband of Connie. He feels shocked because Connie has relationship with a person who is a gamekeeper.

Getting angry, feeling sad and shocked, and firing Mellors as gamekeeper in his estate are the reaction of Clifford after getting information about Connie's scandal with Mellors. Then he does not want to fulfill Connie's demand for divorcing her. The aim of a writer is to stimulate these emotions of a reader to get new experience from it. The findings of evidences and analysis that is made by the writer makes the readers know more and understand clearly about Connie's adultery. It can be concluded that Connie's adultery with Mellors has more than one motivation. 


\section{BIBLIOGRAPHY}

Barnes and Noble. 1983. Lady Chatterley's Lover. Retrieved December 12, 2009, fromhttp://search.barnesandnoble.com/Lady-Chatterleys Lover/D.H\%20Lawrence/e/9780553212624\#EXC

Budianta, Melani, et. al. 2003. Membaca Sastra (Pengantar Memahami Sastra untuk Perguruan Tinggi). Magelang: Indonesia Tera

Burt, Daniel S. 2001. The Biography Book: a Reader's Guide to Nonfiction, Fictional, and Film Biographies of More than 500 of the Most Fascinating Individuals of all Time. Westport: The Oryx Press,

Cliffs Notes. 2000. What is a dynamic character? What is a static character? Retrieved May 8, 2010, from http://www.cliffsnotes.com/Section/id305408, articleld-7986.html

Cohen, B. Bernard. 1963. Writing about Literature. USA:Scott, Foresman and Company.

Crawford , F. Marion. 1893. The Novel: What it is. Boston: Macmillan and Co.,

Cummings, Michael J. 2009. Literary Terms Including Figures of Speech. Retrieved May 13, 2010, from http://www.cummingsstudyguides.net/xLitTerms.html

Dominian, Jack. 1995. Marriage:The Definitive Guide to What Makes a Marriage work. Great Britain: Cedar Edition, William Heinemann Ltd.

Fowler, Alastair. 1982. An Introduction of the theory of genres and Modes. Oxford: clarendon press.

Gay, L.R and Peter Airasian. 2000. Educational Research ( $6^{\text {th }}$ edition). New Jersey: Prentice Hall Inc.

Holman, C. Hugh. 1996. A Handbook to Literature. New York: The Oddysey Press.

Hornby, A.S. 2005. Oxford Advanced Learners Dictionary of Current English (Revised Edition). Oxford: Oxford University Press.

Jones, Edward. H, Jr. 1968. Outlines of Literature. New York: The Macmillan Company.

Ken Shah, and Prof. Param J. Shah. 2010. Motivation. Retrieved May 13, 2010, from http://www.laynetworks.com/Motivation.html

Kenney, William. 1996. How to Analyze Fiction. New York: Simon \& Schuster, Inc. 
Lawrence, D.H. 2003. Lady Chatterley’s Lover. New York: Penguin Group (USA) Inc,

Liukkone, Petri. Ari Pesonen. 2008. D.H. Lawrence. Retrieved May 1, 2010, from http://www.kirjasto.sci.fi/dhlawren.htm

Newman, Steve. 2009. Lady Chatterley's lover. Retrieved June 11, 2010, from http://bookstove.com/classics/dh-lawrence-lady-chatterleyslover/\#ixzzOqYHXgBMq

Orange Unified school District. n.d. Theme. Retrieved May 8, 2010 from http://www.orangeusd.k12.ca.us/yorba/literary elements.htm

Peters, Donna Ambler, Tad McKeon. 1998. Transforming Home Care: Quality, Cost, and Data Management. New York. The U.S: Aspen Publishers Inc.

Raymond, Obstfeld. 2002. Fiction First Aid: Instant Remedies for Novels, Stories and Scripts. Cincinnati, $\mathrm{OH}$ : Writer's Digest Books.

Richard, Bill. 1995. English Literature $2^{\text {nd }}$ ed. London: MacMillan press, Ltd.

Self Improvement Mentor. 2008. Type of Motivation. Retrieved may 13, 2010, from http://www.self-improvement-mentor.com/types-of-motivation.html

Sex and Society. 2010. Volume I. New York: Marshall Cavendish Corporation.

Sudjiman, Panuti. 1990. Memahami Cerita Rekaan. Jakarta: Gramedia,

Taormina, Agatha. 2005. Structure of Novel. Retrieved December 22, 2009, from www.nvcc.edu/home/ataormina/novels/structure/

The World Book Encyclopedia. 2009. Volume 14. Chicago: World Book Inc.

Vialle, Wilma. Pauline Lysaght. Irina Verenikina. 2005. Psychology for Educators.

Australia: Thomson, Social Science Press

Wiehardt, Ginny. 2009. Flat Character. Retrieved December 22, 2009, from http://fictionwriting.about.com/od/glossary/g/flatcharacters.htm

Weil, Bonnie Eaker. 2002. Understanding Adultery. Retrieved June 3, 2010, from http://www.adulterybusters.com/

Woods, Geraldine. 2008. AP English Literature \& Composition for Dummies. Indiana: Wiley Publishing, Inc. 